\title{
Upaya Meningkatkan Hasil Belajar Siswa Pada Pembelajaran Matematika Melalui Metode Pembelajaran Kooperatif Berbasis Kontekstual Pada Siswa SMA Negeri 2 Gorontalo
}

\author{
Musrin Abdullah Ibrahim \\ Guru SMA Negeri 2 Gorontalo \\ musrin@gmail.com
}

\author{
Received: 04 March 2021; Revised: 26 April 2021; Accepted: 28 July 2021 \\ DOI: http://dx.doi.org/10.37905/aksara.7.3.1165-1170.2021
}

\begin{abstract}
ABSTRAK:
Tujuan dari pelaksanaan PTK yaitu untuk mengatasi berbagai persoalan nyata guna memperbaiki dan meningkatkan kualitas proses pembelajaran guru melalui penerapan pendekatan, model, maupun metode baru, adalah Meningkatkan aktivitas belajar dan hasil belajar siswa kelas XI SMA Negeri 2 Gorontalo dalam Pembelajaran Matematika Realistik pada materi sifat-sifat bangun datar. Dalam pelaksanaan PTK minimal terdiri dari 2 siklus dimana pada masing-masing siklus terdapat 4 tahap/langkah penting, yaitu perencanaan, pelaksanaan tindakan, observasi, dan refleksi.

Pembelajaran dengan menggunakan media pendekatan Kontekstual pada mata pelajaran matematika kelas XI SMA Negeri 2 Gorontalo tahun pelajaran 2019/2020 dapat meningkatkan keaktifan dan hasil belajar matematika. Keaktifan peserta didik sebelum PTK sebesar 32,73\%, kemudian keaktifan peserta didik pada siklus I meningkat sebesar $53,64 \%$, dilanjutkan siklus II sebesar 96,36\%.

Peningkatan keaktifan peserta didik dapat meningkatkan pula hasil belajar matematika peserta didik, nilai hasil belajar matematika peserta didik sebelum PTK mencapai ketuntasan sebesar $31,81 \%$, nilai hasil belajar matematika peserta didik setelah siklus 1 mencapai ketuntasan sebesar 77,27\%, nilai hasil belajar matematika peserta didik setelah siklus II sebesar $95,45 \%$, berarti sudah lebih dari $95 \%$ peserta didik yang memperoleh nilai diatas KKM (75) sehingga sudah memenuhi indikator pencapaian. Ada peningkatan keaktifan dan hasil belajar tersebut setelah pengunaan media pendekatan Kontekstual
\end{abstract}

Kata Kunci : kooperatif, hasil belajar siswa, matematika

\section{PENDAHULUAN}

Pembelajaran adalah proses interaksi peserta didik dengan pendidik dan sumber belajar pada suatu lingkungan belajar. Dengan kata lain, pembelajaran adalah proses untuk membantu peserta didik agar dapat belajar dengan baik Tujuan utama diselenggarakannya proses belajar adalah demi tercapainya tujuan pembelajaran. Tujuan tersebut utamanya adalah keberhasilan peserta didik belajar pada suatu mata pelajaran maupun pendidikan pada umumnya (Krismanto, 2003). 
Matematika sekolah merupakan salah satu mata pelajaran yang diajarkan pada pendidikan dasar dan pendidikan menengah. Dalam pedoman penyusunan Kurikulum Tingkat Satuan Pendidikan dijelaskan bahwa tujuan pengajaran matematika di sekolah antara lain agar siswa memahami konsep matematika, menjelaskan keterkaitan antar konsep, mengaplikasikan konsep secara luwes, akurat, efisien, dan tepat, menggunakan penalaran pada pola dan sifat, melakukan manipulasi matematika dalam membuat generalisasi, menyusun bukti, atau menjelaskan gagasan dan pernyataan matematika, memecahkan masalah yang meliputi kemampuan memahami masalah, merancang model matematika, menyelesaikan model dan menafsirkan solusi yang diperoleh, serta mengkomunikasikan gagasan dengan simbol, tabel, diagram atau media lain untuk memperjelas keadaan atau masalah (Depdiknas: 2006).

Kurikulum Tingkat Satuan Pendidikan (KTSP) yang akan diganti dengan Kurikulum 2013 menjadi acuan sekarang ini antara lain menyatakan bahwa dalam kegiatan pembelajaran, pendidik hendaknya menerapkan berbagai pendekatan, strategi, metode dan teknik pembelajaran yang mendidik secara kreatif, penataan materi pembelajaran secara benar sesuai dengan pendekatan yang dipilih dan karakteristik peserta didik. Pengajaran ini dimulai dari hal-hal konkret dilanjutkan ke hal yang abstrak. Pembelajaran diarahkan agar peserta didik memiliki kemampuan berpikir logis, analitis, sistematis, kritis dan kreatif serta memiliki sikap menghargai matematika dan kegunaannya dalam kehidupan, harapan tersebut tidak sejalan dengan situasi dan kondisi pembelajaran matematika di kelas selama ini dalam belajar adalah pembelajaran secara konvensional dimana peserta didik hanya menerima saja apa yang disampaikan oleh pendidik, urutan penyajian bahan dimulai dari abstrak ke konkret, yang bertentangan dengan perkembangan kognitif peserta didik yang masih ditingkat rendah.

Salah satu karakteristik matematika adalah mempunyai objek yang bersifat abstrak. Sifat abstrak ini menyebabkan banyak peserta didik mengalami kesulitan dalam matematika. Prestasi matematika peserta didik baik secara nasional maupun internasional belum menggembirakan. Rendahnya prestasi matematika peserta didik disebabkan oleh faktor peserta didik yaitu mengalami masalah secara komprehensif atau secara parsial dalam matematika. Selain itu, belajar matematika peserta didik belum bermakna, sehingga pengertian peserta didik tentang konsep sangat lemah.

Materi Trigonometri suatu sudut adalah salah satu materi operasi hitung bilangan yang diajarkan pada semester 1 Kelas XI. Materi ini adalah materi yang tentunya dikaitkan dengan materi-materi sebelumnya. Terkadang pendidik hanya menyampaikan materi Menentukan dan menggunakan nilai perbandingan trigonometri suatu sudut.. Peserta didik tanpa diberi kesempatan untuk mengetahui darimana hal itu diperoleh. Peserta didik mengalami kesulitan ketika dihadapkan pada soal-soal cerita tentang Trigonometri suatu sudut.

Agar proses pembelajaran Trigonometri suatu sudut menjadi bermakna, kontekstual dan tidak membosankan diperlukan model pembelajaran yang berorientasi pada peserta didik, dapat melibatkan peserta didik secara aktif, dan peserta didik dapat menggunakan pengetahuan yang telah dimilikinya untuk mengkonstruk pengetahuan yang baru, dan dapat menuntun peserta didik dalam mengkonstruk pengetahuannya, sehingga dapat menarik minat peserta didik dan menyenangkan.

Sehubungan dengan hal tersebut perlu adanya suatu pembelajaran dengan pendekatan atau metode tertentu yang dapat meningkatkan kemampuan peserta didik dan 
hasil belajar peserta didik. Pada penelitian ini akan diterapkan metode kooperatif Pembelajaran Kooperatif Teman Sebaya berbasis Kontekstual. Pembelajaran ini pada prinsipnya adalah mengembangkan perangkat yang pembelajarannya dirancang dengan metode kooperatif Pembelajaran Kooperatif Teman Sebaya dan perangkat pembelajarannya memenuhi indikator-indikator dengan pendekatan Kontekstual.

Salah satu metode pembelajaran yang berpusat pada peserta didik adalah metode pembelajaran kooperatif. Dalam pembelajaran kooperatif terdapat saling ketergantungan positif di antara peserta didik untuk mencapai tujuan pembelajaran. Setiap peserta didik mempunyai kesempatan yang sama untuk sukses. Aktivitas belajar berpusat pada peserta didik dalam bentuk diskusi, mengerjakan tugas bersama, saling membantu dan saling mendukung dalam memecahkan masalah. Melalui interaksi belajar yang efektif, peserta didik lebih termotivasi, percaya diri, mampu menggunakan strategi berpikir tingkat tinggi, serta mampu membangun hubungan interpersonal.

\section{METODE PENELITIAN}

Penelitian ini merupakan tindakan kelas (Classroom Action Research), bertujuan untuk memecahkan masalah-masalah melalui penerapan langsung di kelas atau tempat kerja. Penelitian ini direncanakan dua siklus yang masing - masing siklus terdiri dari 4 tahap yaitu : Perencanaan, Implementasi, pengamatan dan evaluasi serta refleksi.

Pengembangan Instrumen untuk Mengukur Keberhasilan Tindakan nstrumen yang diperlukan dalam penelitian tindakan kelas (PTK) haruslah sejalan dengan prosedur dan langkah PTK. Instrumen untuk mengukur keberhasilan tindakan dapat dipahami dari dua sisi yaitu sisi proses dan sisi hal yang diamati.

Data penelitian dikumpulkan melalui : Pengamatan pembelajaran sebelum penelitian, yang terasa begitu berat dalam mengajarkan Trigonometri suatu sudut di Kelas XI SMA Negeri 2 Gorontalo. Pengisian angket oleh siswa sebelum dan sesudah penelitian dilakukan. Pengisian lembar pengamatan proses pembelajaran selama penelitian oleh kolaborator dan peneliti sendiri. Melalui tes (pretes dan postes) materi penelitian sebelum dan sesudah tindakan dilakukan.

\section{HASIL DAN PEMBAHASAN \\ Hasil Penelitian}

Dari hasil penelitian keaktifan di atas dapat kita lihat adanya peningkatan rata-rata kelima keaktifan peserta didik dari sebelum tindakan, siklus I dan siklus II. Dimana pada sebelum tindakan keaktifan peserta didik mencapai $32,73 \%$ pada siklus I mencapai 53,64\%, dan pada siklus II mencapai 96,36\%. Peningkatan keaktifan belajar diikuti peningkatan hasil belajar, ada kenaikan $20,91 \%$ dari sebelum tindakan ke siklus I dan kenaikannya $42,72 \%$ dari siklus I ke siklus II.

Sehingga dapat dijelaskan bahwa pada sebelum tindakan rata-rata prosentase hasil belajar 31,81\%, masih dikatakan rendah. Dari KKM yang sudah ditetapkan yaitu 75, baru 7 peserta didik dari 22 peserta didik yang mendapat nilai diatas KKM (75). Berarti masih ada 15 peserta didik yang masih berada di bawah KKM. Hal ini menunjukkan bahwa guru belum dapat meningkatkan hasil belajar peserta didik karena ada beberapa faktor yang salah satunya yaitu guru belum menggunakan media pendekatan Kontekstual pada pembelajaran matematika. 
Ditindak lanjuti pada siklus 1 menggunakan media pendekatan Kontekstual pada pembelajaran matematika yang memberikan hasil lebih baik pada siklus I yaitu mencapai $77,27 \%$ dibanding sebelum tindakan, tetapi belum memenuhi indikator pencapaian KKM. Pada siklus 2 untuk memperoleh hasil yang maksimal menggunakan media pendekatan Kontekstual dengan rata-rata prosentase hasil belajar lebih baik jika dibandingkan dengan siklus 1 sebesar 95,45\% sehingga mengalami peningkatan hasil belajar peserta didik dari siklus ke siklus.

Sesuai realita diatas menunjukkan bahwa menggunakan media pendekatan Kontekstual dapat meningkatkan keaktifan dan hasil belajar Matematika tentang memahami trigonometri, pada peserta didik Kelas XI SMA Negeri 2 Gorontalo, sehingga dinyatakan yaitu "Dengan penggunaaan media pendekatan Kontekstual dapat meningkatkan keaktifan belajar peserta didik Kelas XI SMA Negeri 2 Gorontalo Tahun Pelajaran 2019/2020", karena setelah siklus 2 penggunaan media pendekatan Kontekstual dapat meningkatkan keaktifan dan hasil belajar peserta didik pada mata pelajaran matematika.

\section{Pembahasan}

Berdasarkan hasil pelaksanaan pada Siklus I, dan siklus II dapat dinyatakan bahwa pembelajaran matematika menggunakan media pendekatan Kontekstual dapat meningkatkan keaktifan dan prestasi belajar peserta didik Kelas XI SMA Negeri 2 Gorontalo.

Pembahasan hasil penelitian ini didasarkan pada hasil pengamatan dilanjutkan dengan refleksi pengamatan pada setiap siklus tindakan. Dari refleksi pengamatan siklus I pembelajaran menggunakan media pendekatan Kontekstual belum dilaksanakan dengan baik, karena guru belum sepenuhnya dapat memotivasi peserta didik untuk aktif dalam proses pembelajaran. Keaktifan peserta didik pada siklus I masih tergolong rendah namun hasil ini sudah cukup baik dan mengalami peningkatan dibandingkan dengan sebelum tindakan PTK, begitu juga pada siklus II.

Perkembangan hasil belajar peserta didik sebagai berikut ;

$\Rightarrow$ Peserta didik memperhatikan pelajaran dengan sungguh-sunguh,

$\Rightarrow$ Kemauan untuk menerima pelajaran dari guru meningkat,

$\Rightarrow$ Perhatian dan motivasi peserta didik terhadap pelajaran dan pengajar meningkat,

$\Rightarrow$ Peserta didik sudah mampu aktif mengikuti pelajaran,

$\Rightarrow$ Peserta didik sudah berani untuk bertanya dan mengajukan pendapat,

$\Rightarrow$ Kerjasama kelompok sudah terjalin baik,

$\Rightarrow$ Tugas individu dan kelompok terlaksana dengan baik,

$\Rightarrow$ Peserta didik mau untuk mencatat dan merangkum bahan pelajaran tanpa disuruh,

$\Rightarrow$ Pembentukan kelompok diskusi sudah terarah dan berjalan sesuai alokasi waktu.

Rekapitulasi nilai dan penjelasan yang telah disampaikan di atas dapat ditarik kesimpulan bahwa dengan menggunakan media pendekatan Kontekstual dalam pembelajaran Matematika dapat membuat peserta didik menjadi antusias, lebih aktif, tidak malu atau enggan bertanya, lebih tertarik dengan pembelajaran yang dilakukan, memiliki rasa ingin tahu yang tinggi, sehingga peserta didik yang memiliki keaktifan rendah dapat meningkat karena peserta didik merasa senang dengan pembelajaran yang dilakukan peneliti. Hal ini secara tidak langsung juga membawa dampak positif lain yaitu nilai belajar peserta didik yang semula termasuk dalam kategori rendah dapat meningkat 
menjadi kategori tinggi. Dengan motivasi yang tinggi dalam mengikuti pelajaran maka penguasaan materi trigonometri dengan baik oleh peserta didik.

\section{PENUTUP}

Pembelajaran dengan menggunakan media pendekatan Kontekstual pada mata pelajaran matematika Kelas XI SMA Negeri 2 Gorontalo tahun pelajaran 2019/2020 dapat meningkatkan keaktifan dan hasil belajar matematika. Keaktifan peserta didik sebelum PTK sebesar 32,73\%, kemudian keaktifan peserta didik pada siklus I meningkat sebesar 53,64\%, dilanjutkan siklus II sebesar 96,36\%.

Peningkatan keaktifan peserta didik dapat meningkatkan pula hasil belajar matematika peserta didik, nilai hasil belajar matematika peserta didik sebelum PTK mencapai ketuntasan sebesar 31,81\%, nilai hasil belajar matematika peserta didik setelah siklus 1 mencapai ketuntasan sebesar 77,27\%, nilai hasil belajar matematika peserta didik setelah siklus II sebesar 95,45\%, berarti sudah lebih dari $95 \%$ peserta didik yang memperoleh nilai diatas KKM (75) sehingga sudah memenuhi indikator pencapaian. Ada peningkatan keaktifan dan hasil belajar tersebut setelah pengunaan media pendekatan Kontekstual.

\section{DAFTAR PUSTAKA}

Arikunto, Suharsimi. 2009. Penelitian Tindakan Kelas. Jakarta: Bumi Aksara.

Depdiknas. 2006. Model Pelatihan dan Pengembangan Silabus. Jakarta: Departemen Pendidikan Nasional.

Krismanto, Al. 2003. Beberapa Teknik, Model, dan Strategi Dalam Pembelajaran Matematika. Yogyakarta: Departemen Pendidikan Nasional Direktorat jenderal Pendidikan Dasar Dan Menengah Pusat Pengembangan Penataran Guru (PPPG) Matematika.

http://www.anneahira.com/pengertian-prestasi-belajar-menurut-para-ahli.htm Diakses tanggal 22 Oktober 2013.

Krismanto, Al. (2003). Beberapa Teknik, Model, dan Strategi dalam Pembelajaran Matematika. Yogyakarta: Makalah disajikan dalam pelatihan instruktur/pengembang SMU.

Slavin, Robert E. 2010. Cooperative Learning Teori, Riset, dan Praktek. Bandung: Penerbit Nusa Media.

Trianto. 2007. Model-model Pembelajaran Inovatif Berorientasi Konstruktivistik. Jakarta: Prestasi Pustaka Publisher. 
AKSARA: Jurnal Ilmu Pendidikan Nonformal

P-ISSN 2407-8018 E-ISSN 2721-7310 DOI prefix $\underline{10.37905}$

Volume 07, (03) September 2021

http://ejurnal.pps.ung.ac.id/index.php/Aksara 